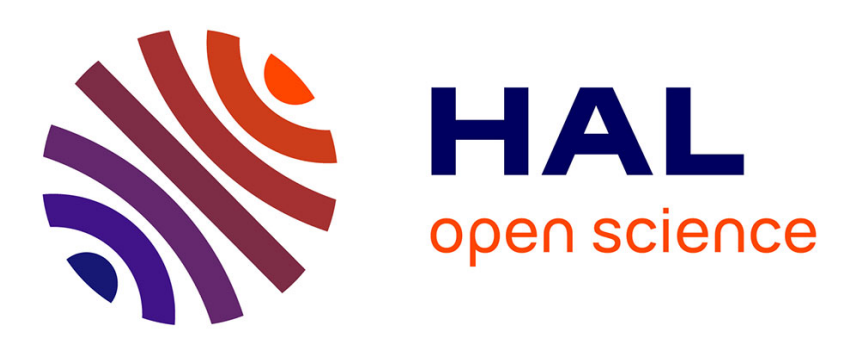

\title{
Oxidation of factor VIII increases its immunogenicity in mice with severe hemophilia A
}

Ivan Peyron, Jordan Dimitrov, Sandrine Delignat, Bagirath Gangadharan, Alok Srivastava, Srinivas V. Kaveri, Sébastien Lacroix-Desmazes

\section{- To cite this version:}

Ivan Peyron, Jordan Dimitrov, Sandrine Delignat, Bagirath Gangadharan, Alok Srivastava, et al.. Oxidation of factor VIII increases its immunogenicity in mice with severe hemophilia A. Cellular Immunology, 2018, 325, pp.64-68. 10.1016/j.cellimm.2018.01.008 . hal-01832032

\section{HAL Id: hal-01832032 \\ https://hal.sorbonne-universite.fr/hal-01832032}

Submitted on 6 Jul 2018

HAL is a multi-disciplinary open access archive for the deposit and dissemination of scientific research documents, whether they are published or not. The documents may come from teaching and research institutions in France or abroad, or from public or private research centers.
L'archive ouverte pluridisciplinaire HAL, est destinée au dépôt et à la diffusion de documents scientifiques de niveau recherche, publiés ou non, émanant des établissements d'enseignement et de recherche français ou étrangers, des laboratoires publics ou privés. 
Oxidation of factor VIII increases its immunogenicity in mice with severe hemophilia A

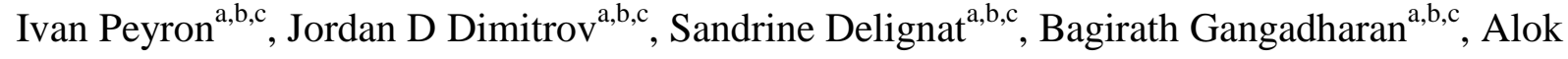
Srivastava $^{\mathrm{d}}$, Srinivas V Kaveri ${ }^{\mathrm{a}, \mathrm{b}, \mathrm{c}}$, Sébastien Lacroix-Desmazes ${ }^{\mathrm{a}, \mathrm{b}, \mathrm{c},{ }^{*}}$

${ }^{a}$ INSERM, UMR S 1138, Centre de recherche des Cordeliers, Paris, F-75006 France; ${ }^{\mathrm{b}}$ Université Pierre et Marie Curie-Paris6, UMR S 1138, Centre de recherche des Cordeliers, Paris, F-75006 France; ' Université Paris Descartes, UMR S 1138, Centre de recherche des Cordeliers, Paris, F-75006 France. ${ }^{\mathrm{d}}$ Department of Haematology, Christian Medical College, Vellore, India.

*Corresponding author: Sébastien Lacroix-Desmazes, INSERM UMR S 1138 Equipe Kaveri, Centre de recherche des Cordeliers, Paris, F-75006 France - Tel : 0144278202 Fax : 0144278193 - sebastien.lacroix-desmazes@crc.jussieu.fr

Keywords: Hemophilia A, factor VIII, factor VIII inhibitors, oxidation, immunogenicity

Word count in abstract: 162

Word count in text: 2937

Figures: 3

Number of references: 20 


\begin{abstract}
The development of antibodies against therapeutic factor VIII (FVIII) represents the major complication of replacement therapy in patients with severe hemophilia A. Amongst the environmental risk factors that influence the anti-FVIII immune response, the presence of active bleeding or hemarthrosis has been evoked. Endothelium damage is typically associated with the release of oxidative compounds. Here, we addressed whether oxidation contributes to FVIII immunogenicity. The control with N-Acetyl cysteine of the oxidative status in FVIIIdeficient mice, a model of severe hemophilia A, reduced the immune response to exogenous FVIII. Ex vivo exposure of therapeutic FVIII to $\mathrm{HOCl}$ induced a mild oxidation of the molecule as evidenced by the loss of free amines and resulted in increased FVIII immunogenicity in vivo when compared to native FVIII. The increased immunogenicity of oxidized FVIII was not reverted by treatment of mice with N-Acetyl cysteine, and did not implicate an increased maturation of professional antigen-presenting cells. Our data document that oxidation influences the immunogenicity of therapeutic FVIII.
\end{abstract}

Keywords: Hemophilia A, oxidative stress, FVIII immunogenicity, FVIII inhibitors 


\section{Introduction}

The onset of an anti-factor VIII (FVIII) immune response, characterized by the development of antibodies targeting coagulation FVIII (FVIII inhibitors) represents the major complication of replacement therapy in patients with hemophilia A. While the pathogenesis of FVIII inhibitor development is not completely understood, several genetic and non-genetics risk factors have been suggested to affect the initiation of the anti-FVIII immune response [1]. Among the non-genetic risk factors, the presence of immuno-stimulatory events such as bleedings have been suggested to favor the development of FVIII inhibitors. In particular, an adjuvant effect of hemarthrosis on inhibitor development has been described in a rat model of severe hemophilia A [2]. While the conclusions of this study support that the presence of hemarthrosis at the time of FVIII infusion is associated with an increased incidence of inhibitor development, the underlying mechanisms are still unclear.

Bleeding episodes are consecutive to endothelium damage which leads to the release of several pro-inflammatory mediators, including reactive oxygen species (ROS), at the site of injury [3]. In addition to effects on immune and non-immune cells that are present in the vicinity of the bleeding site, ROS generate numerous chemical modifications on proteins (e.g., deamination, hydrolysis or oxidation), that influence their structure, function and immunogenicity [4-6]. Thus, Van Beers et al. demonstrated that the oxidative-dependent generation of aggregates of human interferon- $\beta$ increases its immunogenicity, whereas the non-oxidative generation of aggregates does not [7]. Accordingly, the generation of aggregates involving a metal-catalyzed oxidation process increases the immunogenicity of interferon alpha2b [8]. Similar observations were generated in the case of model antigens that do not necessarily correspond to therapeutic proteins. In this case, the oxidative modification of type II collagen by hydroxyl radicals increases both its immunogenicity and 
arthritogenicity in rats [9], and the oxidation of ovalbumin with $\mathrm{HOCl}$ increases its immunogenicity in OTII mice by facilitating endocytosis and processing [10].

Coagulation factors, including FVIII, are concentrated at the site of bleeding and are therefore likely to be exposed to pro-oxidative compounds. Moreover, FVIII is sensitive to oxidation [11] and the production of recombinant FVIII in oxygen free conditions preserves its procoagulant activity [12], probably by protecting FVIII from oxidative alterations. In the present study, we aimed at deciphering the participation of oxidative stress and the effect of oxidation on the immunogenicity of therapeutic FVIII.

\section{Material and methods}

\subsection{Preparation of FVIII}

FVIII (Helixate NexGen, CSL-Behring, Marburg, Germany) was dialyzed against HEPES buffer $\left(150 \mathrm{mM} \mathrm{NaCl}, 10 \mathrm{mM}\right.$ HEPES, $2.5 \mathrm{mM} \mathrm{CaCl} \mathrm{pH}^{2}$ 7.4) for $2 \mathrm{hr}$ at $4^{\circ} \mathrm{C}$. FVIII was mixed with $\mathrm{NaOCl}$ (Sigma-Aldrich, Darmstadt, Germany) at various molar ratios and incubated at $4{ }^{\circ} \mathrm{C}$ for $30 \mathrm{~min}$. The $\mathrm{NaOCl}$ concentration was determined by absorbance measurement at $292 \mathrm{~nm}$ using a molar extinction coefficient of $350 \mathrm{M}^{-1} \mathrm{~cm}^{-1}$. FVIII was then dialyzed against HEPES buffer for an additional $2 \mathrm{hr}$ and concentration was determined by optical density at $280 \mathrm{~nm}$. FVIII activity (FVIII:C) was determined using a chromogenic assay (Siemens, Marburg, Germany) using human plasma as standard. Loss of free amines was measured by fluorescamine fluorescence [13]. Briefly, $20 \mu \mathrm{l}$ of native or HOCl-treated FVIII $(1 \mu \mathrm{M})$ was added to $730 \mu \mathrm{l}$ of borate buffer $(200 \mathrm{mM}, \mathrm{pH} 8.5)$ and mixed while $250 \mu \mathrm{l}$ of fluorescamine $(20 \mu \mathrm{M})$ was added with vortexing. Following incubation at $25^{\circ} \mathrm{C}$ for $15 \mathrm{~min}$, fluorescence was measured between 420 and $600 \mathrm{~nm}$ using an excitation wavelength of $390 \mathrm{~nm}$. Carbonyl groups were quantified using a commercial ELISA kit (OxySelect Carbonyl ELISA). 


\subsection{Animals}

Mice were 6- to 8-week-old C57B16/J-exon 16 knock-out mice. Animals were handled in agreement with local ethical authorities. Treatment with $N$-Acetyl-L-cystein (NAC, SigmaAldrich) was performed by dissolving NAC in drinking water at $142 \mathrm{~g} / \mathrm{l}$ and changed every two days. ORAC values were determined in plasma, using a commercial kit and the antioxidant Trolox ${ }^{\circledR}$ as a standard (OxySelect ${ }^{\mathrm{TM}}$ ORAC Activity assay, CellBiolabs, Inc. San Diego, CA, USA). For FVIII treatment, mice were given $0.2 \mu \mathrm{g}$ native or HOCl-treated FVIII intravenously in $200 \mu \mathrm{l}$ PBS once a week for 4 weeks. Three days after the fourth administration of FVIII, blood was collected from the retro-orbital sinus. Serum was stored at $-20^{\circ} \mathrm{C}$ until use.

\subsection{Measurement of anti-FVIII IgG}

ELISA plates were coated overnight at $4^{\circ} \mathrm{C}$ with recombinant FVIII $(2 \mu \mathrm{g} / \mathrm{ml}$, recombinate, Baxter, Maurepas, France). Plates were blocked with PBS 1\% BSA. Serum in dilution was then incubated for $1 \mathrm{hr}$ at $37^{\circ} \mathrm{C}$. Bound $\mathrm{IgG}$ was revealed with a HRP-coupled monoclonal antimouse IgG antibody (Southern Biotech) and substrate. The mouse monoclonal anti-FVIII IgG mAb6 (a gift from Prof J. M. Saint-Remy, KUL, Belgium) was used as a standard.

\subsection{Measurement of FVIII inhibitors}

Mouse sera were decomplemented by incubation at $56^{\circ} \mathrm{C}$ for $30 \mathrm{~min}$. Serial dilutions of decomplemented sera (ranging from 1:3 to 1:729) were incubated volume/volume with normal human plasma for 2 hours at 37C. Residual FVIII activity was determined using a chromogenic assay. The serum dilution yielding $50 \%$ reduction of FVIII activity was used to represent the inhibitor titer and expressed in Bethesda units (BU) 


\subsection{Maturation of monocyte-derived dendritic cells (MO-DCs)}

Monocytes from peripheral blood mononuclear cells of healthy donors were isolated using anti-CD14 magnetic beads (Miltenyi Biotec, Bergisch Gladbach, Germany) from heparinized buffy coats. To obtain immature monocyte-derived DCs, monocytes $\left(0.5 \times 10^{6}\right.$ cells per $\left.\mathrm{ml}\right)$ were cultured in RPMI-1640 supplemented with penicillin/streptomycin and 10\% FCS, in the presence of $2000 \mathrm{U} / \mathrm{ml} \mathrm{GM-CSF}$ and $1000 \mathrm{U} / \mathrm{ml}$ IL-4 for 5 days. Five-days old immature MO-DCs $\left(250,000 /\right.$ well in X-VIVO $\left.{ }^{15}\right)$ were seeded in 24-well plates and incubated with native or HOCl-treated FVIII $(1 \mu \mathrm{g})$ for $24 \mathrm{hr}$. LPS $(1 \mu \mathrm{g} / \mathrm{ml})$ was used as a positive control. The expression of maturation markers was analyzed by flow cytometry using PE- or FITClabeled antibodies against HLA-DR, CD40, CD80, CD86 and CD83 (all from BD bioscience).

\subsection{Statistical analysis}

All statistical analyses were performed using the GraphPad Prism 6.01 software (GraphPad Software, Inc, La Jolla, California, USA). Statistical significance was assessed using the nonparametric double-sided Mann-Whitney $U$-test or two-way ANOVA with Bonferroni post-test. Differences were considered significant when $\mathrm{p}<0.05$. ns: not significant.

\section{Results and discussion}

3.1. Treatment with $\mathrm{N}$-acetyl cystein increases the anti-oxidant potential of plasma and decreases the immunogenicity of FVIII in FVIII-deficient mice.

The impact of bleeding on the immunogenicity of therapeutic FVIII has been the object of recent studies both in mice and in rats. While bleeding in mice was not associated with higher titers of anti-FVIII antibodies [14], recent study by Lovgren et al. reported an increased incidence of anti-FVIII IgG in a model of rats with hemophilia A [2]. In the present work, we 
hypothesized that the release of ROS associated with vascular damages increases FVIII immunogenicity. To get an insight at the pro-oxidative status in FVIII-deficient mice, we first investigated the effect of the anti-oxidant compound, N-acetyl cysteine (NAC) in vivo. FVIIIdeficient mice were fed with water supplemented with NAC for one week. The oxidant radical absorbance capacity (ORAC) was then determined on fresh plasma. As shown in figure 1A, supplementation of FVIII-deficient mice with NAC resulted in significantly increased ORAC values when compared to control mice. This demonstrates that treatment with NAC reduces the systemic oxidative status of hemophilic mice.

We then investigated the impact of the treatment with NAC on the development of the antiFVIII immune response. Mice receiving or not NAC in drinking water were injected with FVIII once a week for four weeks. As depicted in figure 1B, the treatment with NAC significantly decreased the intensity of the anti-FVIII IgG titers. To further understand the role of oxidation on FVIII immunogenicity, we then addressed the effect of oxidation on FVIII.

\subsection{Effects of hypochloric acid treatment on FVIII structure and activity}

Several studies have described the deleterious effects of oxidation on protein activity, stability and immunogenicity. Hence, the oxidative modification of residues exposed at the surface of proteins (including amino-acid side chains and carbohydrates) generates neo-epitopes with a higher susceptibility to trigger activation of the immune system. Advanced oxidation protein products (AOPP) generated following exposure of albumin to $\mathrm{HOCl}$ were found to activate neutrophils and monocytes [15], and to potentiate the activation of T cells by AOPP-loaded dendritic cells [16]. Therefore, we first characterized the effect of mild oxidation by $\mathrm{HOCl}$ on FVIII structure and function. Increasing amounts of $\mathrm{HOCl}$, ranging from 0 to 50 molar excess, were incubated with FVIII; unreacted $\mathrm{HOCl}$ was then removed by dialysis. The activity of FVIII was then assessed using a chromogenic assay. Incubation of FVIII with 
$\mathrm{HOCl}$ resulted in a dose-dependent reduction of FVIII activity that reached $50 \%$ in the case of 50-fold molar excess of $\mathrm{HOCl}$ (Figure 2A). We then investigated the presence of oxidative modifications on FVIII following exposure to $\mathrm{HOCl}$. Oxidation of amino groups by $\mathrm{HOCl}$ generally results in the progressive disappearance of free $\alpha$ and $\varepsilon$ amino side chains, followed by the formation of aldehyde groups [17]. We determined the generation of carbonyl groups on HOCl-exposed FVIII, as compared to native FVIII. There was a marginal, yet not significant, appearance of carbonyl groups on the FVIII molecule (Figure 2B). We then determined the loss of free amines on FVIII following exposure to $\mathrm{HOCl}$. Native or HOClexposed FVIII were incubated with fluorescamine, a compound that reacts with free amines. There was a dose-dependent and saturable reduction in the fluorescence emission spectrum of fluorescamine upon exposure of FVIII to $\mathrm{HOCl}$ (Figure 2C). Importantly, exposure of FVIII to up to 25 -fold molar excess of $\mathrm{HOCl}$ did not alter the interaction of FVIII with von Willebrand factor (Figure 2D), and with a panel human and mouse monoclonal anti-FVIII antibodies (Figure 2E, F and data not shown).

\subsection{Treatment of FVIII with $\mathrm{HOCl}$ increases its immunogenicity}

The oxidation of self and foreign antigens has been repeatedly shown to increase antigen immunogenicity $[7,8,18]$. In order to determine the importance of oxidative alterations of FVIII, we exposed human recombinant FVIII to an excess of $\mathrm{HOCl}$ in vitro and administered FVIII to FVIII-deficient mice. Three days after the fourth injection of FVIII, the anti-FVIII IgG titers were 1.7-fold higher in mice that received FVIII exposed to a 25 -fold molar excess of $\mathrm{HOCl}(1272 \pm 127 \mu \mathrm{g} / \mathrm{ml})$ as compared to mice treated with native FVIII $(716 \pm 97 \mu \mathrm{g} / \mathrm{ml}$, $\mathrm{P}<0.001$, Figure 3A). Similarly, FVIII inhibitory titers were 1.8 -fold higher in mice treated with FVIII exposed to 25-fold molar excess of $\mathrm{HOCl}$ (475 \pm 159 Bethesda units) as compared to mice treated with native FVIII (262 \pm 99 Bethesda units, $\mathrm{P}<0.05$, Figure 3B) 
Since the intensity of the anti-FVIII immune response in vivo was decreased upon treatment with NAC, we wondered if supplementation of mice with NAC could also prevent the increase anti-FVIII IgG titer observed in the case of FVIII exposed to HOCl. As depicted in figure $3 \mathrm{~A}$ and $\mathrm{B}$, treatment of FVIII-deficient mice with NAC was ineffective in decreasing the intensity of the anti-FVIII immune response in the case of pre-oxidized FVIII. This suggests that the in situ oxidation of exogenously administered FVIII by the oxidative environment contributes to the immunogenicity of FVIII in FVIII-deficient mice, although this remains to be directly confirmed. Because the mild oxidation of FVIII induced upon exposure to $\mathrm{HOCl}$ results in an increased immunogenicity, we investigated whether FVIII oxidation has an impact on innate immune cells in vitro. To investigate a potential effect of oxidized FVIII on the maturation state of antigen-presenting cells, we used human MO-DCs from healthy donors. Five-day-old immature MO-DCs were incubated alone or with $1 \mu \mathrm{g}$ of FVIII exposed or not to 25 molar excess of $\mathrm{HOCl}$. As depicted in figure $3 \mathrm{C}$, the exposure of FVIII to $\mathrm{HOCl}$ did not alter the maturation profile of MO-DCs: indeed, neither the mean fluorescence intensities of HLA-DR, CD40 and CD80, nor the percentage of cells expressing CD83 and CD86 were modified. In contrast, LPS used as a positive control induced the maturation of MO-DCs, as indicated by the increase in MFI and \% expression of the different maturation markers. Similarly, there was no change in the secretion profile of the cytokines IL-6, IL-8 and IL-10 (data not shown). This could be explained by the relatively low concentration of FVIII employed in our experimental setup that may not be sufficient to induce the maturation of dendritic cells, as compared to the high concentrations of albumin used in previous studies.

\section{Conclusion}


Taken together, our work describes the consequences of FVIII oxidation on its immunogenicity in FVIII-deficient mice. It also identifies the relevance of the systemic oxidative status as a risk factor for immunization against therapeutic FVIII. Oxidative modification of carbohydrate has been described to generate advanced glycation end-products (AGEs) that alter protein immunogenicity. Engagement of the receptor for AGEs (RAGE) was found to increase the secretion of pro-inflammatory cytokines such as IL-2 and TNF- $\alpha$ in monocytes [19]. In line with this, albumin containing AGEs was found to trigger a proinflammatory signaling cascade in RAW macrophages [20]. Whether such adducts originating from carbohydrates, are present on the FVIII molecule and whether they participate in triggering the anti-FVIII immune response remain to be determined.

\section{Acknowledgements}

This work was supported by INSERM, CNRS, UPMC-Paris6. IP was a recipient of a fellowship from Ministère de l'enseignement supérieur et de la recherche (France). We thank Dr Marc Jacquemin (University of Leuven, Centre for Molecular and Vascular Biology, Leuven, Belgium) for sharing the human monoclonal anti-FVIII IgG, BO2C11 and BOIIB2.

\section{Author contributions}

IP and SLD planned the work. IP, JDD and SD performed experiments. IP, JDD, BG, SD, AS and SLD analyzed the data. IP, SVK and SLD wrote the paper. SLD was the principal investigator and takes primary responsibility for the paper

The authors declare no conflict of interest 


\section{References}

[1] J. Astermark, C. Altisent, A. Batorova, M.J. Diniz, A. Gringeri, P.A. Holme, A. Karafoulidou, M.F. Lopez-Fernández, B.M. Reipert, A. Rocino, M. Schiavoni, M. von Depka, J. Windyga, K. Fijnvandraat, European Haemophilia Therapy Standardisation Board, Non-genetic risk factors and the development of inhibitors in haemophilia: a comprehensive review and consensus report., Haemophilia. 16 (2010) 747-66.

[2] K.M. Lövgren, H. Søndergaard, S. Skov, B. Wiinberg, Joint bleeds increase the inhibitor response to human factor VIII in a rat model of severe haemophilia A., Haemophilia. (2016) 1-8.

[3] S.P. Alom-Ruiz, N. Anilkumar, A.M. Shah, Reactive oxygen species and endothelial activation, Antioxid Redox Signal. 10 (2008) 1089-1100.

[4] S. Hermeling, D.J. Crommelin, H. Schellekens, W. Jiskoot, Structure-immunogenicity relationships of therapeutic proteins, Pharm Res. 21 (2004) 897-903.

[5] D. Weiskopf, A. Schwanninger, B. Weinberger, G. Almanzar, W. Parson, S. Buus, H. Lindner, B. Grubeck-Loebenstein, Oxidative stress can alter the antigenicity of immunodominant peptides., J. Leukoc. Biol. 87 (2010) 165-72.

[6] J.A. Trujillo, N.P. Croft, N.L. Dudek, R. Channappanavar, A. Theodossis, A.I. Webb, M.A. Dunstone, P.T. Illing, N.S. Butler, C. Fett, D.C. Tscharke, J. Rossjohn, S. Perlman, A.W. Purcell, The cellular redox environment alters antigen presentation., J. Biol. Chem. 289 (2014) 27979-91.

[7] M.M. van Beers, M. Sauerborn, F. Gilli, V. Brinks, H. Schellekens, W. Jiskoot, Oxidized and aggregated recombinant human interferon beta is immunogenic in human interferon beta transgenic mice, Pharm Res. 28 (2011) 2393-2402.

[8] S. Hermeling, H. Schellekens, C. Maas, M.F. Gebbink, D.J. Crommelin, W. Jiskoot, Antibody response to aggregated human interferon alpha2b in wild-type and transgenic 
immune tolerant mice depends on type and level of aggregation, J Pharm Sci. 95 (2006) 1084-1096.

[9] U. Shahab, S. Ahmad, Moinuddin, K. Dixit, S. Habib, K. Alam, A. Ali, Hydroxyl radical modification of collagen type II increases its arthritogenicity and immunogenicity, PLoS One. 7 (2012) e31199.

[10] Z.M. Prokopowicz, F. Arce, R. Biedron, C.L. Chiang, M. Ciszek, D.R. Katz, M. Nowakowska, S. Zapotoczny, J. Marcinkiewicz, B.M. Chain, Hypochlorous acid: a natural adjuvant that facilitates antigen processing, cross-priming, and the induction of adaptive immunity, J Immunol. 184 (2010) 824-835.

[11] T.W. Stief, J. Kurz, M.O. Doss, J. Fareed, Singlet oxygen inactivates fibrinogen, factor V, factor VIII, factor X, and platelet aggregation of human blood, Thromb Res. 97 (2000) 473-480.

[12] T. Osterberg, A. Fatouros, Oxygen-reduced aqueous solution of factor VIII, (1999).

[13] P. Bohlen, S. Stein, W. Dairman, S. Udenfriend, Fluorometric assay of proteins in the nanogram range, Arch Biochem Biophys. 155 (1973) 213-220.

[14] I. Peyron, J.D. Dimitrov, S. Delignat, B. Gangadharan, C. Planchais, S. V. Kaveri, S. Lacroix-Desmazes, Haemarthrosis and arthropathy do not favour the development of factor VIII inhibitors in severe haemophilia A mice., Haemophilia. 21 (2015) 1-4.

[15] V. Witko-Sarsat, V. Gausson, A.T. Nguyen, M. Touam, T. Drueke, F. Santangelo, B. Descamps-Latscha, AOPP-induced activation of human neutrophil and monocyte oxidative metabolism: a potential target for $\mathrm{N}$-acetylcysteine treatment in dialysis patients, Kidney Int. 64 (2003) 82-91.

[16] C.J.J. Alderman, S. Shah, J.C. Foreman, B.M. Chain, D.R. Katz, The role of advanced oxidation protein products in regulation of dendritic cell function., Free Radic. Biol. Med. 32 (2002) 377-85. 
[17] C.L. Hawkins, D.I. Pattison, M.J. Davies, Hypochlorite-induced oxidation of amino acids, peptides and proteins, Amino Acids. 25 (2003) 259-274.

[18] H. Schellekens, Factors influencing the immunogenicity of therapeutic proteins, Nephrol Dial Transpl. 20 Suppl 6 (2005) vi3-9.

[19] A.M. Schmidt, O. Hori, R. Cao, S.D. Yan, J. Brett, J.L. Wautier, S. Ogawa, K. Kuwabara, M. Matsumoto, D. Stern, RAGE: a novel cellular receptor for advanced glycation end products, Diabetes. 45 Suppl 3 (1996) S77-80.

[20] M.P. Cohen, E. Shea, S. Chen, C.W. Shearman, Glycated albumin increases oxidative stress, activates NF-kappa B and extracellular signal-regulated kinase (ERK), and stimulates ERK-dependent transforming growth factor-beta 1 production in macrophage RAW cells, J Lab Clin Med. 141 (2003) 242-249. 


\section{Legend to Figure}

Figure 1. Control of the oxidative status in FVIII-deficient mice reduces the immune response to FVIII. Panel A. FVIII-deficient mice (HemB6) were fed for one week with normal water or water supplemented with $0.142 \mathrm{~g} / 1$ of $N$-Acetyl-L-cystein (HemB6+NAC). The oxidant radical absorbance capacity (ORAC) values were determined in the plasma using a commercial kit and the anti-oxidant Trolox ${ }^{\circledR}$ as a standard. ORAC values of individual mice are expressed as " $\mu \mathrm{M}$ Trolox-equivalent". Panel B and C. HemB6 mice were fed with NAC-containing or normal drinking water. One week after start of NAC feeding, mice received 1 IU FVIII (Helixate®, CSL-Behring, Marburg) intravenously once a week for four weeks. Three days after the fourth administration of FVIII, anti-FVIII IgG titers were determined in plasma by ELISA, using the monoclonal antibody mAb6 as a standard (Panel B). In parallel, inhibitor titers were determined using the Bethesda assay (Panel C). Symbols in panels $\mathrm{A}, \mathrm{B}$ and $\mathrm{C}$ represent individual mice. Horizontal bars depict means \pm SEM. Statistical differences were assessed using the double-sided non-parametric Mann-Whitney $U$-test $(* \mathrm{p}<0.05, * * \mathrm{p}<0.01)$.

Figure 2. Modification of FVIII by HOCl. Panel A. Exposure of FVIII with HOCl reduces FVIII pro-coagulant activity. FVIII $(1 \mu \mathrm{M})$ was exposed to increasing amounts of $\mathrm{HOCl}$ for $30 \mathrm{~min}$ at $4^{\circ} \mathrm{C}$ and the residual FVIII activity was determined using a chromogenic assay. Results are depicted as mean \pm SEM and are representative of 7 independent experiments. Panel B. Detection of carbonyl groups was performed by ELISA. Results are depicted as fold increase in carbonyl content as compared to unexposed FVIII. Data are depicted as mean \pm SEM of 5 independent experiments. Panel C. Analysis of the loss of free amine groups by fluorescamine binding. Following incubation of FVIII alone or in the presence of $\mathrm{HOCl}$, FVIII $(20 \mathrm{nM})$ was incubated with fluorescamine $(5 \mu \mathrm{M})$ in borate buffer. The emission of 
fluorescence was recorded between 420 and $600 \mathrm{~nm}$ after excitation at $390 \mathrm{~nm}$. The emitted fluorescence is expressed as arbitrary units (A.U.). The inset depicts the results obtained from 3 independent experiments (mean \pm SEM). Statistical comparison on panels A and B were performed using the double-sided non-parametric Mann-Whitney $U$-test $(* * * \mathrm{p}<0.001)$ between the conditions with 0 and $50 \mu \mathrm{M} \mathrm{HOCl}$.

Figure 3. Exposure of FVIII to HOCl increases the immunogenicity of FVIII in vivo. Panel A and B. Native FVIII or FVIII exposed to 25-fold excess of $\mathrm{HOCl}\left(\mathrm{FVIII}_{\mathrm{HOCl}}, 0.2 \mu \mathrm{g}\right)$ were administered intravenously once a week for four weeks to FVIII-deficient mice. Three days after the last administration, blood was collected from the retro-orbital sinus and antiFVIII IgG titres were determined in the serum by ELISA (Panel A) and using the Bethesda assay (Panel B). Results represent mean \pm SEM from 8 to 34 mice per group. The statistical significance of differences between groups was assessed using a one-way ANOVA with Dunn's multiple comparison test $(* *$ : $p<0.01)$. HOCl-exposed FVIII was devoid of endotoxin as assessed using the LAL assay. Panel C. Five-day old immature human MO-DCs from three individual donors were incubated alone or in the presence of native or FVIII exposed to 25-fold excess of $\mathrm{HOCl}\left(\mathrm{FVIII}_{\mathrm{HOCl}}, 1 \mu \mathrm{g}\right)$ for 24 hours. Up-regulation of co-stimulatory molecules was determined by flow cytometry. 
Figure 1

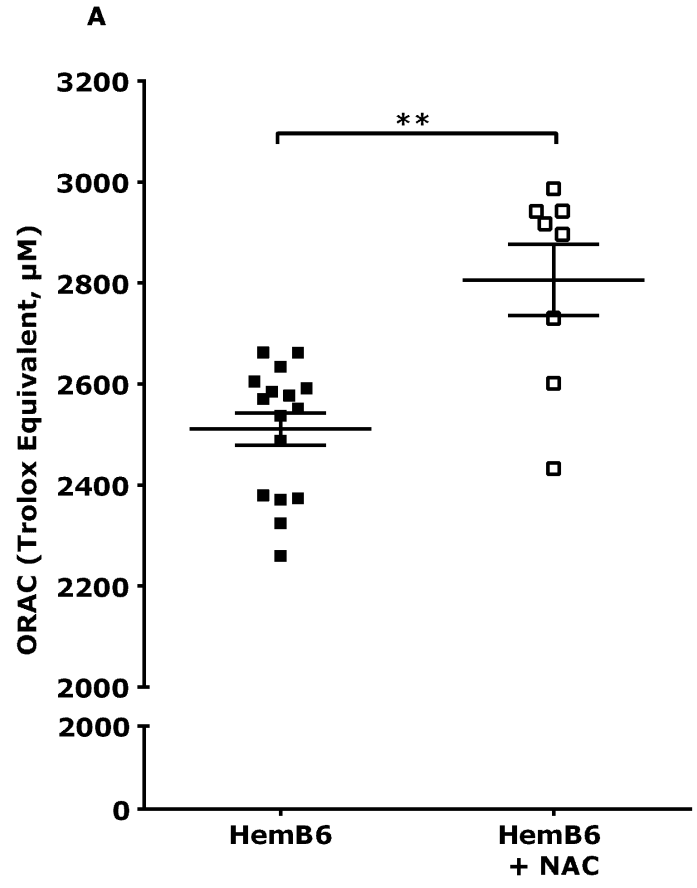

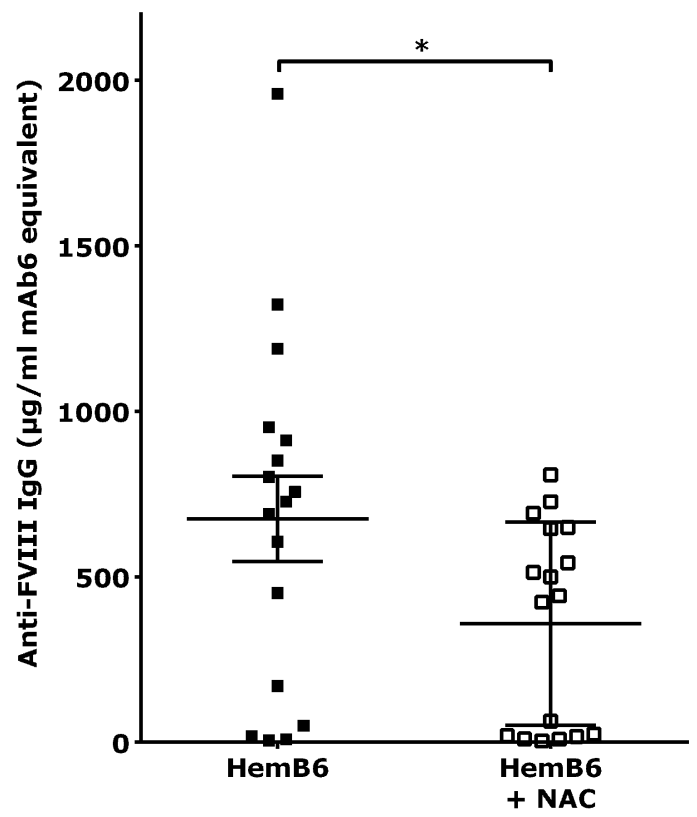


Figure 2
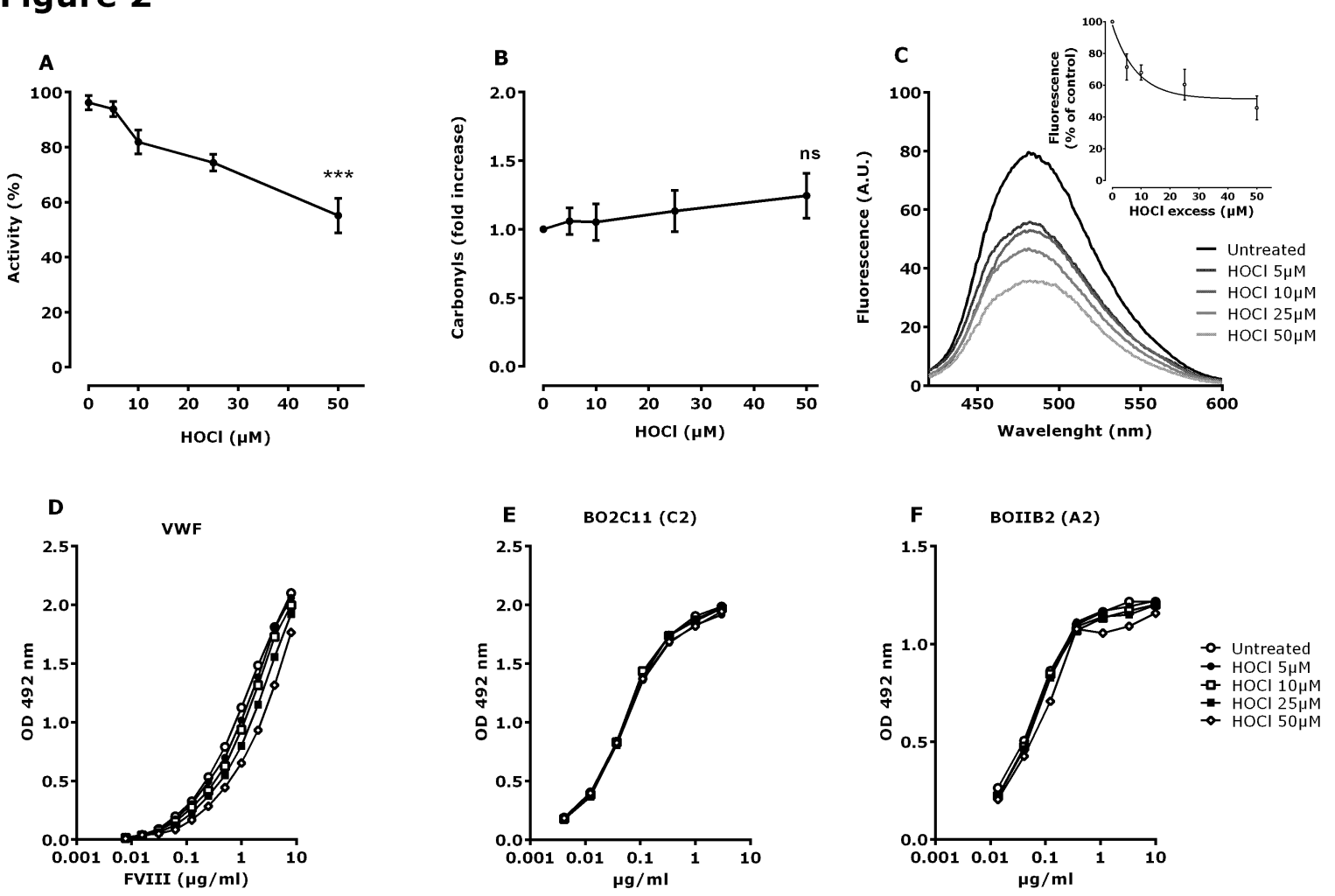
Figure 3
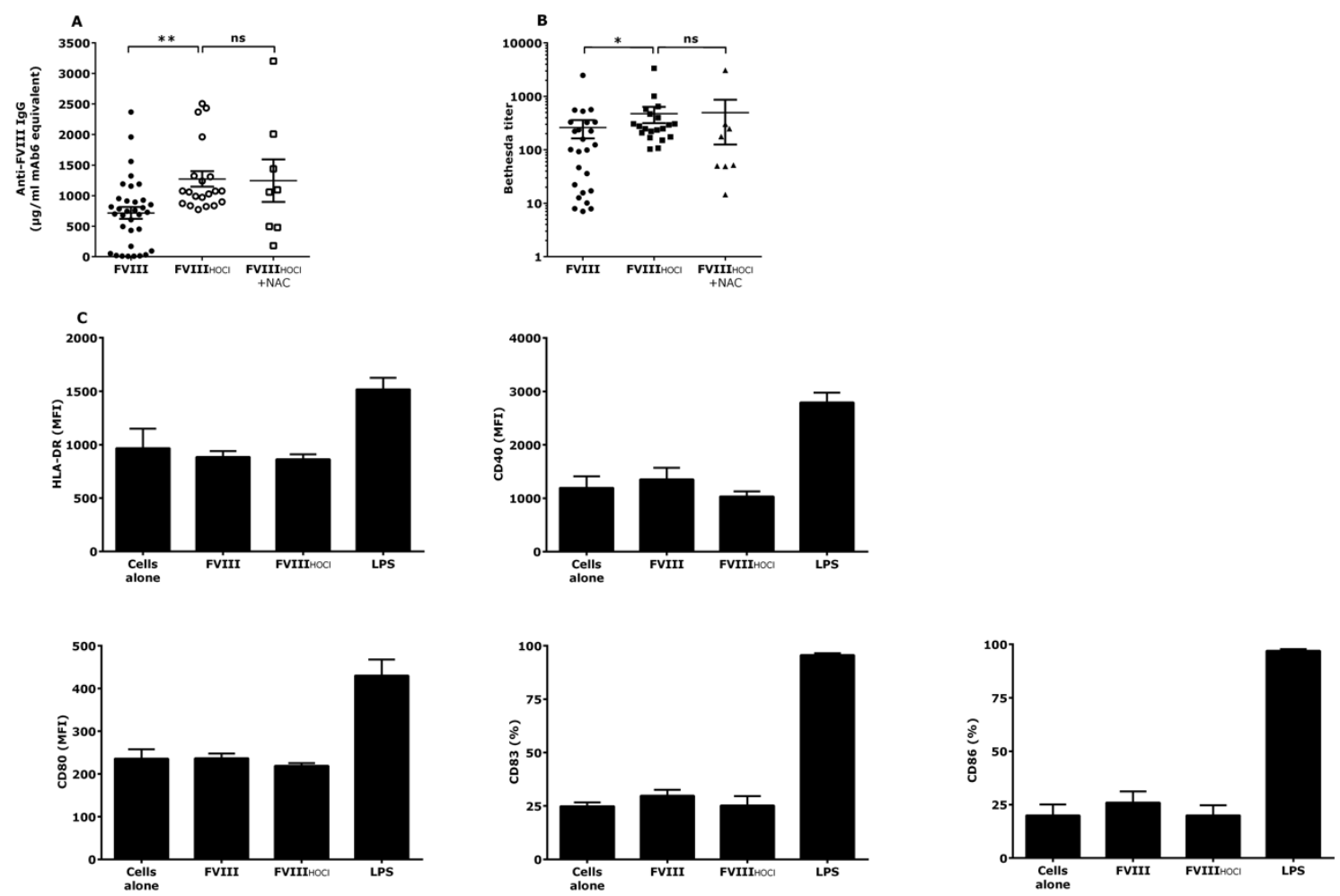